\title{
Understanding farmers perceptions about climate change: a study in a North Indian State
}

\author{
Mohammad Aslam Ansari, Sharad Joshi, Rupan Raghuvanshi \\ Department of Agric, Communication, College of Agriculture, GB Pant University of Ag \& Tech, India
}

Correspondence: Mohammad Aslam Ansari, Department of Agric, Communication, College of Agriculture, GB Pant University of Ag \& Tech, India, Email aslam I405@yahoo.com

Received: July 09, 2018 | Published: July 25, 2018

Copyright@ 2018 Ansari et al. This is an open access article distributed under the terms of the Creative Commons Attribution License, which permits unrestricted use, distribution, and reproduction in any medium, provided the original author and source are credited.

\begin{abstract}
Perceptions not only shape knowledge but knowledge also shapes perceptions about an object, event or phenomena. Farmers' perceptions about climate change, therefore, strongly affects how they understand and deal with climate induced risks and uncertainties, and undertake specific measures to mitigate the adverse impact of climate change on agriculture. The present study was undertaken to ascertain farmers' perceptions about climate change and determine factors affecting it. The study was conducted in two purposively selected districts in the state of Uttar Pradesh (India) which were deemed to be vulnerable to climate change. The study sample comprised of 120 farmers selected randomly. The findings showed that farmers have fairly high level of perception about climate change and its various dimensions. Further, age, education, occupation, farming experience, knowledge about coping strategies, and mass media ownership and exposure were found to be significantly related with farmers' perception about climate change. Hence, an appropriate policy framework and specific programmes for sustainable agriculture growth are needed for enhancing farmers' perception towards climate change and for promoting climate smart agriculture.
\end{abstract}

Keywords: farmers' perceptions, climate change, climate mitigation, climate smart agriculture, adaptation strategies

\section{Introduction}

Climate change, according to IPCC, ${ }^{1}$ refers to any change in climate overtime, whether due to natural variability or as a result of human activity. Raghuvanshi et $\mathrm{al}^{2}$ observed that climate change has emerged as an integral component of development dialogue and debate globally as it is affecting all the countries, developed or developing. Climate is said to be one of the primary determinant of agriculture productivity. United Nations (UN) as well as several national governments are worried that climate change may endanger world food security. Studies have indicated that India is particularly vulnerable to climate change, and is likely to suffer with damages to agriculture productivity, food and water security, human health and cattle populations. Hence, the governments of developing countries are more worried about the adverse impact and its implications. Further, peoples livelihoods, especially in rural areas, are dependent on agriculture, and climate change poses a direct and serious threat to the livelihoods of millions of people in India.

Perceptions not only shape knowledge but knowledge also shapes perception. Farmers' perceptions about climate change, therefore, strongly affects how they deal with climate induced risks and uncertainties, and undertake specific measures by coping strategies to mitigate the adverse impact of climate change on agriculture. Raghuvanshi et al. ${ }^{3,4}$ reiterated that farmers' perception is the key to mitigating adverse impact of climate change on agriculture; and recommended that specific interventions targeting the farming community as well as other stakeholders needs to be undertaken to improve their preparedness in dealing with its adverse impact. Consequently, the present study was undertaken to study "Understanding farmers' Farmers' Perception about Climate Change".

\section{Materials and methodology}

The study was conducted in two purposively selected districts in Uttar Pradesh (U.P), the largest state in India. The study sample comprised of 120 farmers selected randomly from four purposively selected villages spread over four blocks. The selection of districts, blocks and villages was based on the estimated vulnerability of these areas to climate change as determined by National Initiative on Climate Resilient Agriculture (NICRA) of Indian Council of Agriculture Research (ICAR), Government of India in 2011. The data was collected using a pre-tested structured interview schedule and collected data was analysed using SPSS (version 17).

The state of U.P. has long suffered due to many climate changes. Two districts selected for the study - one from East and the second in West. The Eastern parts of the State have suffered from severe floods during the rainy seasons and Western part i.e. Bundelkhand region, has been affected perennially by extended period of drought and severe heat stress which limits the agriculture productivity, thus jeopardizing people's livelihoods in rural areas. Climate related disasters and extreme events have brought widespread gloom and huge economic losses, adversely affecting food security, agriculture productivity, water resources, public health, and biodiversity in the state.

\section{Results and discussion}

\section{Socio-demographic profile of the respondents}

A number of profile characteristics were selected as independent variables to find out profile of farmers of the study area. The results obtained are given in Table 1. It is evident from the above table that majority of respondents $(62.50 \%)$ in the study sample were in 
'young age' category followed by $35 \%$ respondents in the 'middle age' category; and $30.83 \%$ respondents were illiterate. Gender-wise composition of the study sample reveals that large majority of them (98.33\%) were males; $78 \%$ having 'medium family size; $88.33 \%$ having 'farming' as their major occupation but only $12 \%$ having high farming experience whereas majority $85 \%$ reported having 'low' farming experience. As regards land holding, $20 \%$ respondents were marginal farmers, $29 \%$ small and $47.5 \%$ having 'medium' land holding. Majority of farmers (56\%) reported 'low' annual income followed by medium (24\%) and low (19\%). Further, majority of the respondents $(44 \%)$ reported 'medium' decision making ability, followed by $33 \%$ displaying 'high' and only $22 \%$ reporting 'low' decision making ability. As regards their economic motivation, $62.5 \%$ had 'high motivation' followed by $35 \%$ having 'medium' motivation. Additionally, majority of the respondents (71\%) displayed medium scientific orientation. Mass media ownership was quite interesting as $93 \%$ of the farmers reported to own a mobile followed by Radio $(51 \%)$, Television $(57 \%)$ and Newspapers accounting for only $25 \%$. However, as regards media exposure, majority of them reported 'low' media exposure followed by medium (23\%) and low (16\%) only. Further, a large majority of respondents (91\%) displayed 'medium' information seeking behaviour.

Table I Distribution of respondents according to their socio-demographic profile $(\mathrm{N}=120)$

\begin{tabular}{|c|c|c|c|}
\hline SI. No. & Variables & Frequency & Percentage \\
\hline \multirow[t]{4}{*}{ I } & Age & & \\
\hline & Young & 75 & 62.5 \\
\hline & Middle & 42 & 35 \\
\hline & Old & 3 & 2.5 \\
\hline \multirow[t]{7}{*}{2} & Education & & \\
\hline & Illiterate & 37 & 30.83 \\
\hline & Primary level & 13 & 10.83 \\
\hline & Middle level & 17 & 14.16 \\
\hline & High school level & 12 & 10 \\
\hline & Intermediate & 26 & 21.67 \\
\hline & Graduate and above & 15 & 12.5 \\
\hline \multirow[t]{3}{*}{3} & Gender & & \\
\hline & Male & 118 & 98.33 \\
\hline & Female & 2 & 1.67 \\
\hline \multirow[t]{4}{*}{4} & Family Size & & \\
\hline & High & 21 & 17.5 \\
\hline & Medium & 94 & 78.34 \\
\hline & Low & 5 & 4.16 \\
\hline \multirow[t]{3}{*}{5} & Occupation & & \\
\hline & Farming & 106 & 88.33 \\
\hline & Farming with others & 14 & 11.67 \\
\hline \multirow[t]{3}{*}{6} & Farming Experience & & \\
\hline & High & 15 & 12.5 \\
\hline & Medium & 2 & 1.67 \\
\hline
\end{tabular}

Table I continue..

Low

7

\section{Land Holding}

Marginal (less than I hectare)

Small (I-2 hectare)

20

Medium (2- 10 hectare)

Large (more than 10

hectare)

\section{Annual Income}

$\begin{array}{lll}\text { High } & 23 & 19.16 \\ \text { Medium } & 29 & 24.17 \\ & 68 & 56.17\end{array}$

9

Decision Making Ability

High

Medium

Low

10

Economic Motivation

High $\quad 75 \quad 62.5$

$\begin{array}{lll}\text { Medium } & 43 & 35.83\end{array}$

Low

Scientific Orientation

High

Medium

9

Low

Mass Media Exposure

$\begin{array}{lll}\text { High } & 20 & 16.67\end{array}$

Medium

Low

60

Mass Media Ownership

$\begin{array}{lll}\text { Radio } & 62 & 51.67\end{array}$

Television $\quad 69$

Newspaper $\quad 30 \quad 25$

$\begin{array}{lll}\text { Mobile } \quad 112 & 93.33\end{array}$

14

Information Seeking Behaviour

$\begin{array}{lll}\text { High } & 8 & 6.66 \\ \text { Medium } & 110 & 91.66 \\ \text { Low } & 2 & 1.67\end{array}$

\section{Perception of farmers about climate change}

It refers to the opinion of farmers towards climate change and its impact on agriculture. The findings regarding farmers' perception about climate change' are given in Figure 1.

It is evident from the findings presented in figure-1 that majority of the farmers $(54.17 \%)$ displayed high level of perception towards climate change followed by medium $(25 \%)$ and low $(20.83 \%)$. The 
findings of the study are similar to Shankara et al. ${ }^{5}$ wherein it was found that the majority of the farmers had high levels of perception about climate change parameters such as temperature, rainfall and dry spells). Further, farmers' perception about different dimensions of climate change was also analysed and the results are given in the following Table 2 .

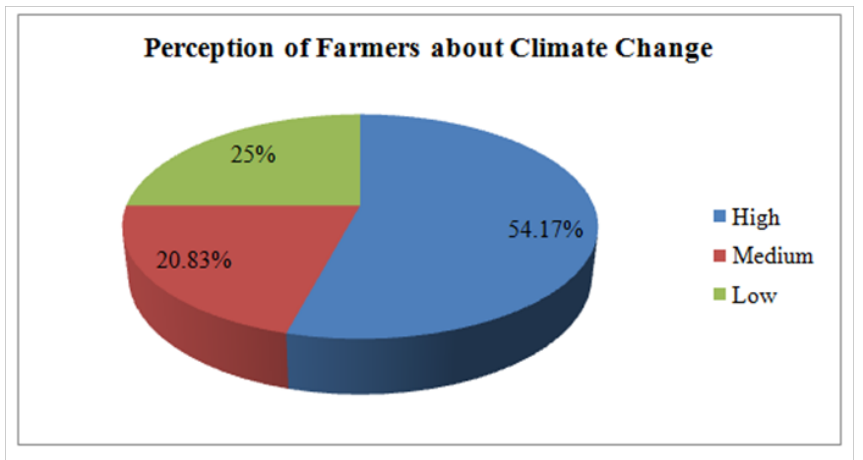

Figure I Distribution of the farmers on the basis their perception about climate change.
A large majority of respondents ( $83 \%)$, as is evident from the above table, agree to the statement that there has been 'an increase in temperature and number of sunny days' and about $68 \%$ agreed that amount of rainfall has also increased as result of climate change. Further, about $80 \%$ of the respondents have said that there has been 'an increase in frequency of heavy rainfall and rains are occurring earlier or later than the expected rainy season. About $75 \%$ of the respondents agreed that 'total number of rainy days' have increased; $85 \%$ percent agreed to the statement that 'duration of dry spell during rainy season has increased, and $79 \%$ agreed that number of sunshine hours during rainy season have decreased. Additionally, $75.8 \%$ respondents agreed that 'intensity of heat during summer has increased', $65 \%$ said told that 'bitterness of cold during winter has increased' and $75.8 \%$ reported that there has been 'a decrease in ground water table' as a result of climate change. On the basis of observations related to Climate Change Dimensions it can be concluded that that majority of the respondents have felt that there has been a significant amount of change in various parameter of climate change. Maddison ${ }^{6}$ observed that adaptation to climate change requires, that farmers should first notice that climate has changed, and then identify useful adaptation strategies and then implement them.

Table 2 Distribution of the farmers according to perception about climate change

\begin{tabular}{|c|c|c|c|c|}
\hline \multirow{2}{*}{ SI. No. } & \multirow[b]{2}{*}{ Climate change dimensions } & \multicolumn{3}{|c|}{ Farmers' Perception $(\mathbf{N}=\mid 20)$} \\
\hline & & Agree & Undecided & Disagree \\
\hline I & Increase in Temperature and number of sunny days & $100(83.33 \%)$ & $4(3.33)$ & $16(13.22 \%)$ \\
\hline 2 & Increase in amount of rainfall & $87(68.33 \%)$ & $13(10.83 \%)$ & $20(16.67 \%)$ \\
\hline 3 & Increase in frequency of heavy rains & $97(80.83 \%)$ & $3(2.50 \%)$ & $20(16.67 \%)$ \\
\hline 4 & $\begin{array}{l}\text { Rains are occurring either earlier or later than the } \\
\text { expected rainy season? }\end{array}$ & $97(80.83 \%)$ & $5(4.17 \%)$ & $18(15.00 \%)$ \\
\hline 5 & Total rainy days have decreased? & $90(75.00 \%)$ & $16(13.33 \%)$ & $14(11.66 \%)$ \\
\hline 6 & Duration of dry spell during rainy season has increased? & $102(85.00 \%)$ & $5(4.17 \%)$ & $13(10.83 \%)$ \\
\hline 7 & $\begin{array}{l}\text { Number of sunshine hours during rainy season have } \\
\text { decreased }\end{array}$ & $95(79.16 \%)$ & $12(10.00 \%)$ & $13(10.83 \%)$ \\
\hline 8 & Intensity of heat during summer has increased? & $91(75.83 \%)$ & $8(6.67 \%)$ & $2 \mathrm{I}(17.50 \%)$ \\
\hline 9 & Bitterness of cold during winter has increased? & $78(65.00 \%)$ & $7(5.83 \%)$ & $35(29.16 \%)$ \\
\hline 10 & Decrease in ground water table & $91(75.83 \%)$ & $5(4.17 \%)$ & $24(20.00 \%)$ \\
\hline
\end{tabular}

\section{Relationship between farmers' Socio-profile characteristics and their Perceptions about climate change}

Correlation coefficient was calculated to find out the relationship between selected independent variables with dependent variable (i.e. farmers' perceptions about climate change). Further, t-test was used to check the significance of the relationship between the two variables. Results obtained are given in Table 3.

Table 3 Relationship between farmers' socio-personal, economic, psychological and communication characteristics and their perceptions about climate change

\begin{tabular}{lll}
\hline S. No. & Independent variable & Karl pearson's 'r' value \\
\hline I & Age & $0.191^{*}$ \\
2 & Gender & 0.114 \\
3 & Education & $0.232^{*}$
\end{tabular}

$\begin{array}{lll}4 & \text { Family size } & 0.092 \\ 5 & \text { Occupation } & 0.322^{* *} \\ 6 & \text { Farming Experience } & 0.204^{*} \\ 7 & \text { Land holding } & 0.028 \\ 8 & \text { Annual income } & 0.013 \\ 9 & \begin{array}{l}\text { Knowledge about Coping } \\ 10\end{array} & 0.188^{*} \\ 11 & \text { Decision making ability } & 0.072 \\ 12 & \text { Sconomic motivation } & -0.012 \\ 13 & \begin{array}{l}\text { Mass media exposure and } \\ \text { ownership }\end{array} & 0.053 \\ 14 & \text { Information seeking behavior } & 0.198^{*}\end{array}$


Findings presented in Table 3 reveals that out of fourteen independent variables, age, gender, education, family size occupation, farming experience, land holding, annual income, knowledge about coping strategy, decision making ability, scientific orientation, mass media exposure, ownership, and information seeking behavior were found to be positively related. Further, it was found that, except economic motivation, all other variables were positively related; these two variables, i.e. annual income and economic motivation were negatively related. Additionally, Age, Education, Occupation, Farming experience, Knowledge about coping strategies, and Mass media exposure were found to be significantly related with farmers' perception about climate change. Akanda \& Howladar ${ }^{7}$ also found that age has a significant positive effect on perception of farmers about climate change. Falaki et al. ${ }^{8}$ concluded that there was a significant relationship between gender and perception of farmers about climate change (drought incidence). Graft \& Onumah ${ }^{9}$ reported that education has a significant positive effect on perception of farmers about climate change. Sofuluwe et al. ${ }^{10}$ found that annual family income has a significant positive effect on perception of farmer about climate change.

\section{Regression analysis: impact of independent variables on dependent variable}

An attempt was made to find out the impact of independent variables on the dependent variable. Multiple Regression analysis was done to predict the dependent variable on the basis of independent variables. First partial regression analysis was done to find out how the fourteen independent variables namely age, gender, education, family size, occupation, farming experience, landholding, annual income, knowledge about coping strategies, decision making ability, economic motivation, scientific orientation, mass media exposure and information seeking behaviour are related with the dependent variable (Farmers' perception towards climate change). Then, regression equations were developed between independent variables and dependent variable (perception of farmers about climate change) along with the values of coefficient of determination. The results obtained are given in Table $4 \& 5$.

Table 4 Partial regression analysis

\begin{tabular}{lll}
\hline Independent variables & $\begin{array}{l}\text { Partial Regression } \\
\text { coefficient (b) }\end{array}$ & $\begin{array}{l}\text { ' } t \text { ' } \\
\text { value }\end{array}$ \\
\hline I.Age & -0.83 I** $^{* *}$ & 3.95 \\
2. Gender & -0.500 & 1.33 \\
3. Education & $-1.314^{*}$ & 2.41 \\
4. Family size & 0.187 & 1.39 \\
5. Occupation & -0.360 & 1.86 \\
6. Farming Experience & 0.222 & 1.19 \\
7. Land holding & -0.172 & 0.97 \\
8. Annual income & 1.053 & 1.18 \\
9. Knowledge about coping strategies & $0.712^{* *}$ & 2.95 \\
10. Decision making ability & 0.829 & 2.50 \\
II. Economic motivation & -0.111 & 1.38 \\
12. Scientific Orientation & 0.122 & 0.52 \\
13. Mass media exposure \& & $-0.829^{*}$ & 3.19 \\
Ownership & 0.213 & 1.12 \\
14. Information seeking behavior & & \\
\hline
\end{tabular}

Table 5 Regression equation for independent variables with dependent variable

\begin{tabular}{lll}
\hline $\begin{array}{l}\text { Dependent } \\
\text { variable }\end{array}$ & Regression equation & $\mathbf{R}^{2}$ \\
\hline $\begin{array}{l}\text { Farmer's } \\
\text { perception }\end{array}$ & $\begin{array}{l}32.68-0.8313 \mathrm{x}_{1}-0.50 \mathrm{x}_{2}-1.31 \mathrm{x}_{3}+0.18 \mathrm{x}_{4}- \\
0.11 \mathrm{x}_{5}+0.22 \mathrm{x}_{6}-0.17 \mathrm{x}_{7}+1.05 \mathrm{x}_{8}+0.71 \mathrm{x}_{9}-0.82 \mathrm{x}_{10}-\end{array}$ & 0.43 \\
& $0.12 \mathrm{x}_{12}-0.82 \mathrm{x}_{13}+0.15 \mathrm{x}_{14}$ & \\
\hline
\end{tabular}

Table 4 reveals that partial regression coefficients for seven independent variables - i.e. age, gender, education, occupation, land holding, economic motivation and mass media exposure \& ownership - were inversely related with farmer's perception towards climate change. This indicates that a unit increase in the value of independent variables will lead to corresponding decrease in the dependent variable. Further, the remaining seven variables (family size, farming experience, and annual income, knowledge about coping strategies, scientific orientation, and information seeking behaviour) were found to be positively related with farmer's perception about climate change. However, the relationship of only four variables, viz. Age, Education, Knowledge about coping strategies, Mass media exposure and ownership was found to be significant.

Further, multiple regression analysis was done and coefficient of determination $\left(\mathrm{R}^{2}\right)$ was calculated to find out the contribution of all the independent variables on the dependent variable (farmers' perception about climate change). The results are given in Table 5 .

It can thus be inferred from the results given in Table 5 that coefficient of determination $\left(\mathrm{R}^{2}\right)$ is 0.43 , which means that only $43 \%$ of the variation in the dependent variable (i.e. farmers' perception about climate change) could be attributed to all the independent variables included under the present study. The remaining $57 \%$ variation in the dependent variable under study could be attributed to other factors/ variables not included in the study. There may be some intervening and/ or extraneous factors which need to be studied in order to arrive at a reliable and valid conclusion about the factors which contribute towards farmers' perception towards climate change. ${ }^{11}$

\section{Conclusion}

Climate change has emerged as one of the critical factor affecting agricultural productivity in India as well globally. More than twothirds of Indian agriculture is rainfed, meaning that it is at the mercy of vagaries of climate. Hence, it would be of utmost concern for the policy makers as well as scientists to figure out the factors which negatively affect agricultural productivity as well as production efficiency. Hence, understanding farmers' perception towards climate change, factors contributing in farmers' perception towards climate change and its negative impact on agriculture productivity will go a long way in ensuring that they adopt appropriate adaptation strategies. It will help in sustainable agriculture growth thereby ensuring food security.

The present study has highlighted that although farmers' perception about climate change is fairly high, but they also display fairly good understanding of various dimensions that contribute to climate change such as increase in temperature. erratic and sporadic rainfall behavior, increase in duration of heat stress due to high temperature, decrease in ground water table and several others. However, many farmers still display low perceptions and are not adequately equipped with knowledge of adaptation, mitigation and resilience strategies in order to foster the adverse impacts of climate change on agriculture. Therefore, it is of significant importance to create awareness by way of 
sustained and high-voltage communication campaigns to educate the farmer about climate change and adaptation strategies. The focus of these campaigns should on young, educated small and medium farmers and mobilize extension services providers to contribute in mitigating adverse impact of climate change on agriculture productivity.

\section{Acknowledgement}

None.

\section{Conflict of interest}

The author declares no conflict of interest.

\section{References}

I. Inter-governmental panel on climate change (IPCC). Impact, Adaptation and Vulnerability Contribution of working group II of the Inter-governmental Panel on Climate change to the third assessment report of IPCC. London: Cambridge University Press; 200I.

2. Raghuvanshi, Rupan, Ansari, et al. Farmers' awareness about climate change and adaptation practices:A review. Journal of Agriculture Science and Technology. 2016;3(3):4I-5I.

3. Raghuvanshi, Rupan,Ansari MA, et al.A study of farmers' awareness about climate change and adaptation practices in India. International Journal of Applied Agriculture Research. 2017;3(6):154-160.
4. Raghuvanshi, Rupan,Ansari, et al.Adaptation to climate change by farmers in Himalayan region of Uttarakhand. Research Journal of Agriculture Sciences. 2018;9(2):399-403.

5. Shankara MH, Shivamurthy M, Kumar KTV. Farmers perception on climate change and its impact on agriculture in eastern dry zone of Karnataka. International Journal of Farm Sciences. 20 I 3:3(2): 100-107.

6. Maddison D. Perception and adaptation to climate change in Africa. CEEPA. Discussion paper No.10. Centre for Environmental Economics and Policy in Africa. Pretoria, South Africa: University of Pretoria; 2006.

7. Akanda MGR, Howlader MS. Coastal Farmers' Perception about Climate Change Effects at GalachipaUpazila under Patuakhali District of Bangladesh. Global Journal Science Frontier Research: Agriculture and Veterinary. 20I5; I5(4):56-66.

8. Falaki AA, Akogbe JA, Ayinde OE. Analysis of climate change and rural farmers' perception in north central Nigeria. Journal of Human Ecology. 20I3;43(2): I 33-140.

9. Graft H, Onumah E. Farmers' perceptions and adaptations to climate change: An estimation of willingness to pay in western Ghana. Agris. 20I I;3(4):3I-39.

10. Sofoluwe N, Tijani A, Baruwa O, Farmers' Perception and adaptations to climate change in Osun State, Nigeria. African Journal of Agricultural Research. 20II;6(20):36-45.

II. Kates R. 'Cautionary tales: Adaptation and the Global poor'. Climate Change. 201 I;45(I):5-7. 